\title{
FTIR, Weight, and Surface Morphology of Poly(vinyl chloride) Doped with Tin Complexes Containing Aromatic and Heterocyclic Moieties
}

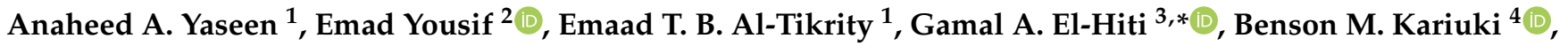 \\ Dina S. Ahmed ${ }^{5}$ and Muna Bufaroosha ${ }^{6}$ \\ 1 Department of Chemistry, College of Science, Tikrit University, Tikrit 34001, Iraq; \\ ch@sc.nahrainuniv.edu.iq (A.A.Y.); emaad1954@tu.edu.iq (E.T.B.A.-T.) \\ 2 Department of Chemistry, College of Science, Al-Nahrain University, Baghdad 64021, Iraq; \\ emad.yousif@nahrainuniv.edu.iq \\ 3 Department of Optometry, College of Applied Medical Sciences, King Saud University, P.O. Box 10219, \\ Riyadh 11433, Saudi Arabia \\ 4 School of Chemistry, Cardiff University, Main Building, Park Place, Cardiff CF10 3AT, UK; \\ kariukib@cardiff.ac.uk \\ 5 Department of Medical Instrumentation Engineering, Al-Mansour University College, Baghdad 64021, Iraq; \\ dina.saadi@muc.edu.iq \\ 6 Department of Chemistry, College of Science, United Arab Emirates University, P.O. Box 15551, \\ Al-Ain 1818, United Arab Emirates; muna.bufaroosha@uaeu.ac.ae \\ check for \\ * Correspondence: gelhiti@ksu.edu.sa; Tel.: +966-11469-3778; Fax: +966-11469-3536
} updates

Citation: Yaseen, A.A.; Yousif, E.; Al-Tikrity, E.T.B.; El-Hiti, G.A.; Kariuki, B.M.; Ahmed, D.S.; Bufaroosha, M. FTIR, Weight, and Surface Morphology of Poly(vinyl chloride) Doped with Tin Complexes Containing Aromatic and Heterocyclic Moieties. Polymers 2021, 13, 3264. https://doi.org/10.3390/ polym13193264

Academic Editor: Michal Sedlačík

Received: 8 September 2021

Accepted: 23 September 2021

Published: 25 September 2021

Publisher's Note: MDPI stays neutral with regard to jurisdictional claims in published maps and institutional affiliations.

Copyright: (c) 2021 by the authors. Licensee MDPI, Basel, Switzerland. This article is an open access article distributed under the terms and conditions of the Creative Commons Attribution (CC BY) license (https:// creativecommons.org/licenses/by/ $4.0 /)$.
Abstract: Poly(vinyl chloride) (PVC) is an important synthetic plastic that is produced in large quantities (millions of tons) annually. Additives to PVC are necessary to allow its use in many applications, particularly in harsh conditions. In regard to this, investigation of the synthesis of trimethoprim-tin complexes and their use as PVC additives is reported. Trimethoprim-tin complexes were obtained from the reaction of trimethoprim and tin chlorides using simple procedures. Trimethoprim-tin complexes ( $0.5 \%$ by weight) were added to PVC to produce homogenous mixtures and thin films were made. The effect of ultraviolet irradiation on the surface and properties of the PVC films was investigated. The level of both photodecomposition and photo-oxidation of PVC films containing trimethoprim-tin complexes was observed to be lower than for the blank film. The effectiveness of tin complexes as PVC photostabilizers reflects the aromaticity of the additives. The complex containing three phenyl groups attached to the tin cation showed the most stabilizing effect on PVC. The complex containing two phenyl groups was next, with the one containing butyl substituents resulting in the least stabilization of PVC. A number of mechanisms have been proposed to explain the role of the synthesized complexes in PVC photostabilization.

Keywords: trimethoprim-tin complexes; poly(vinyl chloride); roughness factor; photodegradation; photo-oxidation; weight loss; functional group index

\section{Introduction}

Plastics are synthetic polymers that can be molded into different shapes. Plastics are cheap, durable, lightweight, and can be used in a myriad of applications. They are effective replacements for glass, wood, and steel [1-3]. Plastics are mainly produced from fossil feedstocks relying on technology that was developed a long time ago. Physical properties of plastics such as strength, color, density, molecular weight, and rigidity can be manipulated during the manufacturing processes. Polyethylene, polypropylene, poly(vinyl chloride) (PVC), polyethylene terephthalate, and polystyrene are the most common synthetic plastics. In Europe, the plastics industry contributed to 1.5 million jobs and generated EUR 350 billion in 2019 [4]. China is the main producer of plastics and contributes $51 \%$ of the 
world's plastics production. Plastics are mainly used in packaging (39.6\%), construction materials $(20.4 \%)$, automotive $(9.6 \%)$, electronics $(6.2 \%)$, household $(4.1 \%)$, agriculture $(3.4 \%)$, and other $(16.7 \%)$ applications [4]. Large quantities (4 million tons) of plastics were recycled and reused in Europe in 2018. However, the recycling process is tedious, energy-, money-, and time-consuming, and involves many steps, namely collection, first sorting, shredding, washing, second sorting, and extrusion [4].

PVC is an important thermoplastic with many advantages. PVC has a low price, high strength and stability, resists attack by chemicals and corrosion in harsh environments, and acts as an electrical insulator, smoke suppressor, and flame retardant due to its high content of chlorine (approximately $57 \%$ by weight) [5]. These properties make PVC suitable for a broad range of applications [6]. The production scale for PVC has increased over the years and this trend will undoubtedly continue into the future [7]. The versatility of PVC can be increased by manipulation of its flexibility to enable its use in applications that require soft polymers via the addition of plasticizers [8]. Plasticizers create free volume by being located between the PVC chains. Another mechanism by which plasticizers soften PVC is through lowering the glass transition temperature $[9,10]$.

A disadvantage of PVC is that it suffers from photodegradation at temperatures above $100{ }^{\circ} \mathrm{C}$ and in the process releases hydrogen chloride $(\mathrm{HCl})$ forming an unstable structure. The elimination of $\mathrm{HCl}$ leads to the formation of polyenes containing conjugated carboncarbon double bonds. The dehydrochlorination process results in deterioration of physical and thermal properties of PVC along with discoloration and therefore limits its outdoor applications [11,12]. Although PVC does not absorb high wavelength UV light $(\lambda>220$ $\mathrm{nm})$, polyene chains produced as a result of defects can initiate photodegradation of the polymer $[13,14]$. It is therefore necessary to use PVC photostabilizers in order to limit the damage caused by photoirradiation [15]. Consequently, there is a continuing need to improve as well as produce new PVC additives.

PVC additives act mainly as quenchers for radicals, peroxides, heat, and UV energy [16,17]. The main role of PVC stabilizers is inhibition of the formation of allylic chlorides and $\mathrm{HCl}[18,19]$. The additives should be used in minimal quantity to avoid color change, be blended well with the polymer, be cheap to produce and involatile. In addition, they should not leak or pose a danger to the environment. Many potential additives are banned from use due to their toxicity and the harm they cause to humans and animals. Banned additives include flame retardants (e.g., chlorinated biphenyls), plasticizers (e.g., phthalates), stabilizers (e.g., phosphites), and those containing metals [20-23]. Various additives such as polyphosphates [24], polybenzimidazoles [25], metal oxides [26-28], pigments [29], Schiff bases [30-34], and substituted tin complexes containing aromatic moieties [35-38] have been used to improve photostability of PVC.

The current work reports the successful synthesis and use of trimethoprim-tin complexes as PVC additives. Trimethoprim inhibits bacterial growth and is used to treat cystitis, acne, and urinary tract and chest infections [39]. It is a colorless solid, commercially available, contains pyrimidine and aryl rings (aromatic moieties), and heteroatoms (nitrogen and oxygen). It can coordinate with the PVC, does not alter the color, absorbs the UV light, and quenches radicals and peroxides. In addition, the tin cation acts as a quencher for the $\mathrm{HCl}$ produced during PVC photodegradation. Therefore, trimethoprim-tin complexes have all the qualities required in a photostabilizer. It is also anticipated that the inclusion of extra aromatic substituents (phenyl groups) on the skeleton of the tin complexes can enhance their ability to photostabilize PVC.

\section{Materials and Methods}

\subsection{General}

Trimethoprim (98\%), triphenyltin chloride $\left(\mathrm{Ph}_{3} \mathrm{SnCl} ; 95 \%\right)$, diphenyltin dichloride $\left(\mathrm{Ph}_{2} \mathrm{SnCl}_{2} ; 96 \%\right)$, di- $n$-butyltin dichloride $\left(n-\mathrm{Bu}_{2} \mathrm{SnCl}_{2} ; 96 \%\right)$, and solvents were purchased from Merck (Gillingham, UK). PVC with an average molecular weight of approximately 233,000 and a polymerization degree of 800 was supplied by Petkim Petrokimya (Istanbul, 
Turkey). The amounts of carbon, hydrogen, nitrogen, and tin within the complexes were determined using a Vario EL III elemental analyzer (Elementar Americas, Ronkonkoma, NY, USA). An FTIR 8400 Shimadzu spectrophotometer (Shimadzu, Tokyo, Japan) was used to record the FTIR spectra. A Bruker DRX-500 NMR spectrometer (Zürich, Switzerland) was used to record the ${ }^{1} \mathrm{H}$ and ${ }^{13} \mathrm{C}$ NMR at 500 and $125 \mathrm{MHz}$, respectively. The NMR spectra were recorded in deuterated dimethyl sulfoxide at $25^{\circ} \mathrm{C}$. The chemical shifts (ppm) were measured relative to tetramethylsilane as a standard. An accelerated weather-meter QUV tester (Q-Panel Company; Homestead, FL, USA) was used at $25{ }^{\circ} \mathrm{C}$ for the UV irradiation of films. The optical images of the surface of samples were captured using a Meiji Techno microscope (Tokyo, Japan). The field emission scanning electron microscopy (FESEM) images were obtained using a SIGMA 500 VP microscope (ZEISS Microscopy, Jena, Germany) in which the accelerating voltage was $15 \mathrm{kV}$ at $25^{\circ} \mathrm{C}$. A Hitachi H-7100 electron microscope (London, UK) was used to record the transmission electron micrograph (TEM) images and a Veeco instrument (Plainview, NY, USA) was used to capture the atomic force microscopy (AFM) images.

\subsection{Synthesis of Complex $\mathbf{1}$}

A solution of $\mathrm{Ph}_{3} \mathrm{SnCl}(0.39 \mathrm{~g}, 1.0 \mathrm{mmol})$ in methanol $(\mathrm{MeOH} ; 5 \mathrm{~mL})$ was added to a stirred solution of trimethoprim $(0.29 \mathrm{~g}, 1.0 \mathrm{mmol})$ in $\mathrm{MeOH}(10 \mathrm{~mL})$. This mixture was heated under reflux for $6 \mathrm{~h}$. The solid produced on cooling was filtered, washed with $\mathrm{MeOH}(2 \times 5 \mathrm{~mL})$, and dried to give $\mathbf{1}$ (Scheme 1$)$ in $75 \%$ yield (Table 1 ).<smiles>COc1cc(Cc2cnc(N)nc2N)cc(OC)c1OC</smiles><smiles>COC(O)c1ccccc1</smiles><smiles></smiles>

Scheme 1. Synthesis of trimethoprim-tin complex 1.

Table 1. Physical properties and elemental composition of 1-3.

\begin{tabular}{cccccccc}
\hline \multirow{2}{*}{ Complex } & \multirow{2}{*}{ Color } & M.P. $\left({ }^{\circ} \mathbf{C}\right)$ & Yield (\%) & \multicolumn{4}{c}{ Elemental Analyses (\%) Calculated (Found) } \\
\cline { 5 - 8 } & & & C & H & N & Sn \\
\hline $\mathbf{1}$ & White & $267-269$ & 75 & $60.12(60.25)$ & $5.05(5.10)$ & $8.76(8.78)$ & $18.57(18.48)$ \\
$\mathbf{2}$ & Off white & $217-218$ & 79 & $56.42(56.36)$ & $5.21(5.25)$ & $13.16(13.23)$ & $13.94(14.01)$ \\
$\mathbf{3}$ & White & $245-246$ & 82 & $53.28(53.27)$ & $6.46(6.39)$ & $13.81(13.89)$ & $14.63(14.76)$ \\
\hline
\end{tabular}

\subsection{Synthesis of Complexes $\mathbf{2}$ and $\mathbf{3}$}

A solution of $\mathrm{Ph}_{2} \mathrm{SnCl}_{2}(0.35 \mathrm{~g}, 1.0 \mathrm{mmol})$ or $n-\mathrm{Bu}_{2} \mathrm{SnCl}_{2}(0.30 \mathrm{~g}, 1.0 \mathrm{mmol})$ in $\mathrm{MeOH}$ $(5 \mathrm{~mL})$ was added to a stirred solution of trimethoprim $(0.58 \mathrm{~g}, 2.0 \mathrm{mmol})$ in $\mathrm{MeOH}(10 \mathrm{~mL})$. The mixture was heated under reflux for $6 \mathrm{~h}$. The solid produced on cooling was filtered, washed with $\mathrm{MeOH}(2 \times 5 \mathrm{~mL})$, and dried to give 2 or 3 (Scheme 2) in 79 or $82 \%$ yield, respectively (Table 1 ). 


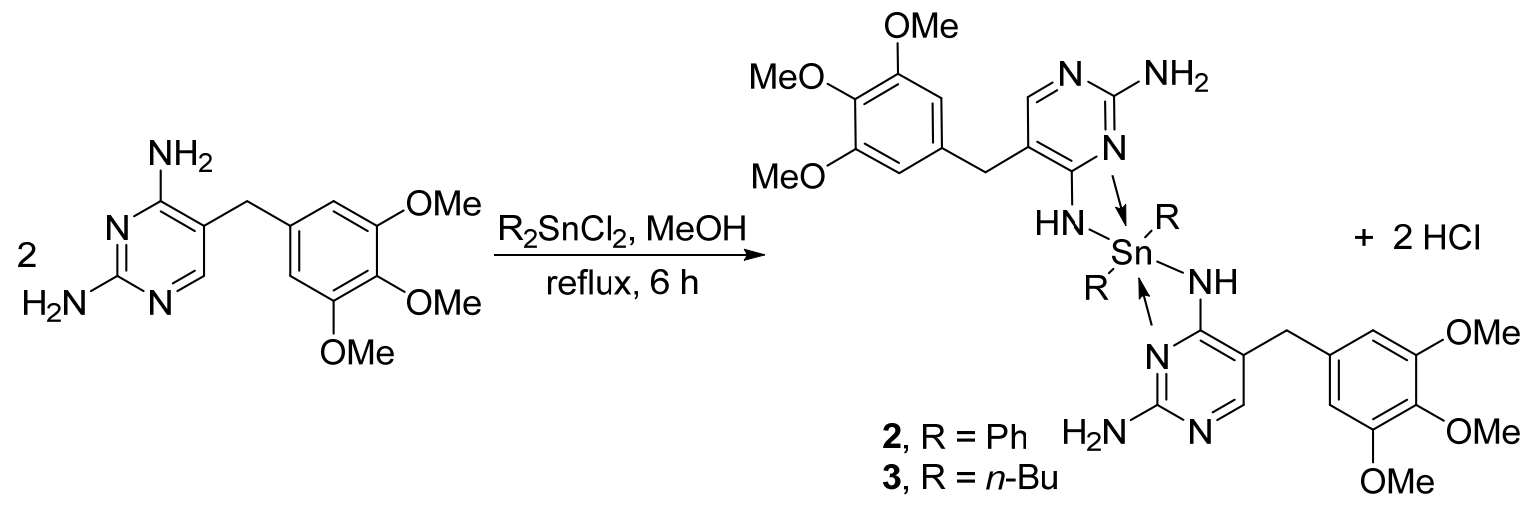

Scheme 2. Synthesis of trimethoprim-tin complexes 2 and 3.

\subsection{Preparation of PVC Films}

Complex 1, 2, or $3(25 \mathrm{mg})$ was added to a magnetically stirred suspension of PVC $(5.0 \mathrm{~g})$ in tetrahydrofuran (THF; $100 \mathrm{~mL}$ ) and the mixture was stirred for $2 \mathrm{~h}$. The homogenous solution obtained was poured onto a clean and dry glass plate $\left(4 \times 4 \mathrm{~cm}^{2}\right)$ containing 15 holes with a thickness of approximately $40 \mu$. The solvent was removed by leaving the plate at $25^{\circ} \mathrm{C}$ for $18 \mathrm{~h}$. The films produced were dried in a vacuum oven $\left(25^{\circ} \mathrm{C}\right)$ for $18 \mathrm{~h}$.

\subsection{Irradiation of PVC Films}

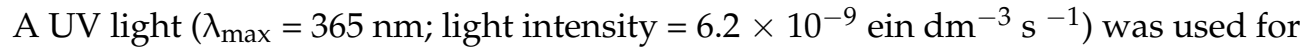
the irradiation of the PVC samples. The sample was rotated regularly to ensure that it was exposed to the light evenly from all sides. The films were irradiated for a time that ranged from 0 to $300 \mathrm{~h}$. The effect the irradiation on the PVC properties was recorded every $50 \mathrm{~h}$.

\subsection{Measurement of PVC Functional Group Indices}

PVC photodegradation leads to the formation of residues that contain $\mathrm{C}=\mathrm{O}$ (carbonyl) and $C=C$ (unsaturated carbons) groups. The growth of the intensity of the bands for both $\mathrm{C}=\mathrm{O}$ and $\mathrm{C}=\mathrm{C}$ groups generated by photoirradiation can be monitored using FTIR spectroscopy and compared with that for the $\mathrm{C}-\mathrm{H}$ bond as a reference [40]. The indices of $\mathrm{C}=\mathrm{O}$ and $\mathrm{C}=\mathrm{C}$ groups (Is) were calculated using Equation (1), where $A_{s}$ and $A_{r}$ are the absorbance of the functional and reference groups, respectively.

$$
I_{S}=A_{S} / A_{r}
$$

\subsection{Measurement of PVC Weight Loss}

PVC photodegradation leads to weight loss due to the elimination of volatile molecules. The weight loss (\%) can be calculated from the weight of the sample pre- $\left(W_{\text {pre }}\right)$ and postirradiation $\left(W_{\text {post }}\right)$ using Equation (2) [41].

$$
\text { Weight loss }(\%)=\left(W_{\text {pre }}-W_{\text {post }}\right) / W_{\text {pre }} \times 100
$$

\section{Results and Discussion}

\subsection{Synthesis of Trimethoprim-tin Complexes 1-3}

The reaction of trimethoprim and $\mathrm{Ph}_{3} \mathrm{SnCl}$ in a 1:1 molar ratio in $\mathrm{MeOH}$ under reflux gave complex 1 (Scheme 1) in 75\% yield (Table 1). Similarly, the reaction of trimethoprim and $\mathrm{Ph}_{2} \mathrm{SnCl}_{2}$ or $n-\mathrm{Bu}_{2} \mathrm{SnCl}_{2}$ in a 2:1 molar ratio under similar reaction conditions gave 2 or 3 (Scheme 2) in 79 or $82 \%$ yield (Table 1). The purity of the synthesized complexes was confirmed by elemental analyses (Table 1 ).

The absorption bands due to vibration of the $\mathrm{NH}_{2}, \mathrm{NH}$, and $\mathrm{C}=\mathrm{N}$ groups appeared in the 3406-3408 $\mathrm{cm}^{-1}, 3163-3180 \mathrm{~cm}^{-1}$, and $1680-1682 \mathrm{~cm}^{-1}$ regions, respectively (Table 2) in the FTIR spectra of 1-3 (Figures S1-S3). In addition, the bands that appeared in the 
$605-507 \mathrm{~cm}^{-1}$ and $497-586 \mathrm{~cm}^{-1}$ regions are attributed to the vibration of the $\mathrm{Sn}-\mathrm{C}$, and Sn-N groups, respectively.

Table 2. FTIR spectral data for trimethoprim-tin complexes 1-3.

\begin{tabular}{cccccc}
\hline \multirow{2}{*}{ Complex } & \multicolumn{5}{c}{ FTIR, Wave Number $\left(\boldsymbol{v}, \mathbf{c m}^{-\mathbf{1}}\right)$} \\
\cline { 2 - 6 } & $\mathbf{N H}_{\mathbf{2}}$ & $\mathbf{N H}$ & $\mathbf{C}=\mathbf{N}$ & $\mathbf{S n}-\mathbf{C}$ & Sn-N \\
\hline $\mathbf{1}$ & 3406 & 3176 & 1680 & 605 & 497 \\
$\mathbf{2}$ & 3408 & 3180 & 1680 & 607 & 586 \\
$\mathbf{3}$ & 3406 & 3163 & 1682 & 605 & 516 \\
\hline
\end{tabular}

The ${ }^{1} \mathrm{H}$ NMR spectra of $\mathbf{1 - 3}$ indicated the presence of the pyrimidine proton that appeared as a singlet at low magnetic field. The NH proton appeared as an exchangeable singlet at high magnetic field due to the shielding effect of the Sn atom. The spectra showed all other protons (Table 3). The ${ }^{13} \mathrm{C}$ NMR spectra of trimethoprim-tin complexes showed the presence of carbons derived from both the trimethoprim unit and substituents (phenyl and butyl groups) attached to the Sn atom (Table 3). Representative NMR spectra are shown in Figures S4 and S5.

Table 3. NMR spectral data of trimethoprim-tin complexes 1-3.

\begin{tabular}{|c|c|c|}
\hline Complex & ${ }^{1} \mathrm{H}$ NMR (DMSO- $d_{6}: \delta, \mathrm{ppm}, J$ in $\mathrm{Hz}$ ) & ${ }^{13}$ C NMR (DMSO- $d_{6}: \delta$, ppm) \\
\hline 1 & $\begin{array}{c}3.16(\mathrm{~s}, \text { exch., } 1 \mathrm{H}, \mathrm{NH}), 3.61\left(\mathrm{~s}, 2 \mathrm{H}, \mathrm{CH}_{2}\right) \\
3.64(\mathrm{~s}, 3 \mathrm{H}, \mathrm{OMe}), 3.76(\mathrm{~s}, 6 \mathrm{H}, 2 \mathrm{OMe}) \\
6.64\left(\mathrm{~s}, 2 \mathrm{H}, 3,4,5-(\mathrm{OMe})_{3} \mathrm{C}_{6} \mathrm{H}_{2}\right), 7.47-7.53 \\
\left(\mathrm{~m}, 17 \mathrm{H}, 3 \mathrm{Ph} \text { and } \mathrm{NH}_{2}\right), 7.95(\mathrm{~s}, 1 \mathrm{H}, \\
\text { pyrimidinyl })\end{array}$ & $\begin{array}{c}32.7\left(\mathrm{CH}_{2}\right), 56.4(\mathrm{OMe}), 60.4(\mathrm{OMe}), \\
106.7\left(\mathrm{C} 2 / \mathrm{C} 6 \text { of } 3,4,5-(\mathrm{OMe}){ }_{3} \mathrm{C}_{6} \mathrm{H}_{2}\right), \\
109.2(\mathrm{C} 5 \text { of pyrimidinyl }), 128.5 \\
(\mathrm{C} 3 / \mathrm{C} 5 \text { of } \mathrm{Ph}), 128.2(\mathrm{C} 4 \text { of } \mathrm{Ph}), 133.7 \\
\left(\mathrm{C} 1 \text { of } 3,4,5-(\mathrm{OMe})_{3} \mathrm{C}_{6} \mathrm{H}_{2}\right), 136.6(\mathrm{C} 4 \\
\left.\text { of } 3,4,5-(\mathrm{OMe})_{3} \mathrm{C}_{6} \mathrm{H}_{2}\right), 137.0(\mathrm{C} 2 / \mathrm{C} 6 \\
\text { of } \mathrm{Ph}), 137.5(\mathrm{C} 1 \text { of } \mathrm{Ph}), 141.0(\mathrm{C} 3 / \mathrm{C} 5 \\
\left.\text { of } 3,4,5-(\mathrm{OMe})_{3} \mathrm{C}_{6} \mathrm{H}_{2}\right), 153.3(\mathrm{C} 4 \text { of } \\
\text { pyrimidinyl }), 161.1(\mathrm{C} 2 \text { of } \\
\text { pyrimidinyl }), 164.3(\mathrm{C} 1 \text { of } \\
\text { pyrimidinyl })\end{array}$ \\
\hline 2 & $\begin{array}{c}3.46 \text { (s, exch., } 2 \mathrm{H}, 2 \mathrm{NH}), 3.56(\mathrm{~s}, 4 \mathrm{H}, 2 \\
\left.\mathrm{CH}_{2}\right), 3.64(\mathrm{~s}, 6 \mathrm{H}, 2 \mathrm{OMe}), 3.74(\mathrm{~s}, 12 \mathrm{H}, 4 \\
\mathrm{OMe}), 6.28\left(\mathrm{~s}, \mathrm{exch}, 4 \mathrm{H}, 2 \mathrm{NH}_{2}\right), 6.59(\mathrm{~s}, \\
\left.4 \mathrm{H}, 3,4,5-(\mathrm{OMe})_{3} \mathrm{C}_{6} \mathrm{H}_{2}\right), 7.26-7.36(10 \mathrm{H}, 2 \\
\mathrm{Ph}), 7.96(\mathrm{~s}, 2 \mathrm{H}, \text { pyrimidinyl })\end{array}$ & $\begin{array}{c}33.2\left(\mathrm{CH}_{2}\right), 56.3(\mathrm{OMe}), 60.4(\mathrm{OMe}), \\
106.4\left(\mathrm{C} 2 / \mathrm{C} 6 \text { of } 3,4,5-(\mathrm{OMe}){ }_{3} \mathrm{C}_{6} \mathrm{H}_{2}\right), \\
107.2(\mathrm{C} 5 \text { of pyrimidinyl }), 127.4 \\
(\mathrm{C} 3 / \mathrm{C} 5 \text { of } \mathrm{Ph}), 127.6(\mathrm{C} 4 \text { of } \mathrm{Ph}), 133.1 \\
\left(\mathrm{C} 1 \text { of } 3,4,5-(\mathrm{OMe})_{3} \mathrm{C}_{6} \mathrm{H}_{2}\right), 135.3(\mathrm{C} 4 \\
\left.\text { of } 3,4,5-(\mathrm{OMe})_{3} \mathrm{C}_{6} \mathrm{H}_{2}\right), 135.5(\mathrm{C} 2 / \mathrm{C} 6 \\
\text { of } \mathrm{Ph}), 136.3(\mathrm{C} 1 \text { of } \mathrm{Ph}), 151.5(\mathrm{C} 3 / \mathrm{C} 5 \\
\left.\text { of } 3,4,5-(\mathrm{OMe})_{3} \mathrm{C}_{6} \mathrm{H}_{2}\right), 153.2(\mathrm{C} 4 \text { of } \\
\text { pyrimidinyl }), 160.4(\mathrm{C} 2 \text { of } \\
\text { pyrimidinyl }), 163.2(\mathrm{C} 1 \text { of } \\
\text { pyrimidinyl })\end{array}$ \\
\hline 3 & 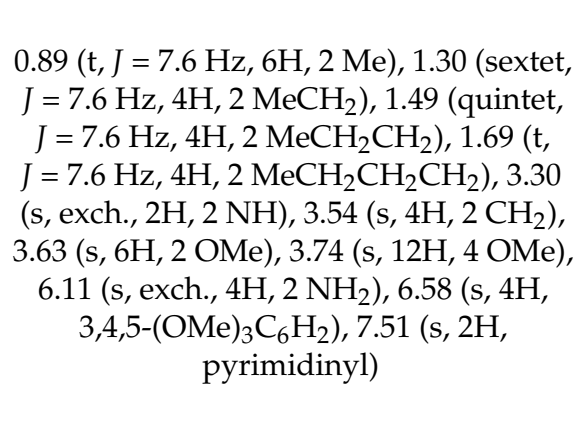 & $\begin{array}{c}14.2(\mathrm{Me}), 16.5\left(\mathrm{SnCH}_{2}\right), 26.1 \\
\left(\mathrm{SnCH}_{2} \mathrm{CH}_{2}\right), 28.1\left(\mathrm{MeCH}_{2}\right), 33.3 \\
\left(\mathrm{CH}_{2}\right), 56.3(\mathrm{OMe}), 60.4(\mathrm{OMe}), 106.4 \\
\left.\mathrm{C} 2 / \mathrm{C} 6 \text { of } 3,4,5-(\mathrm{OMe})_{3} \mathrm{C}_{6} \mathrm{H}_{2}\right), 107.0 \\
(\mathrm{C} 5 \text { of pyrimidinyl }), 135.8(\mathrm{C} 1 \text { of } \\
\left.\text { 3,4,5-(OMe })_{3} \mathrm{C}_{6} \mathrm{H}_{2}\right), 136.3(\mathrm{C} 4 \text { of } \\
\left.3,4,5-(\mathrm{OMe})_{3} \mathrm{C}_{6} \mathrm{H}_{2}\right), 150.0(\mathrm{C} 3 / \mathrm{C} 5 \text { of } \\
\left.\text { 3,4,5-(OMe })_{3} \mathrm{C}_{6} \mathrm{H}_{2}\right), 153.2(\mathrm{C} 4 \text { of } \\
\text { pyrimidinyl }), 161.2(\mathrm{C} 2 \text { of } \\
\text { pyrimidinyl }), 163.1(\mathrm{C} 1 \text { of } \\
\text { pyrimidinyl })\end{array}$ \\
\hline
\end{tabular}




\subsection{Investigation of PVC Photodegradation through FTIR Spectrophotometry}

PVC photodegradation takes place mainly due to the elimination of free radicals (e.g., $\mathrm{Cl} \cdot)$ and the release of $\mathrm{HCl}$. This process of dehydrochlorination is responsible for the formation of short polymeric chains containing $\mathrm{C}=\mathrm{O}$ and $-\mathrm{CH}=\mathrm{CH}$ - moieties [42-44]. As irradiation of PVC progresses, the formation of the $\mathrm{C}=\mathrm{O}$ and $-\mathrm{CH}=\mathrm{CH}-$ becomes noticeably significant. Therefore, FTIR spectroscopy was used to examine the growth of the absorption bands corresponding to the $\mathrm{C}=\mathrm{O}\left(1722 \mathrm{~cm}^{-1}\right)$ and $-\mathrm{CH}=\mathrm{CH}-\left(1602 \mathrm{~cm}^{-1}\right)$ groups during the irradiation process (Figure 1). The intensities of these absorption bands increased substantially during irradiation compared with that for the $\mathrm{C}-\mathrm{H}$ bonds $\left(\mathrm{CH}_{2} ; 1328 \mathrm{~cm}^{-1}\right)$ of the PVC chains. The UV light does not affect the intensity of the absorption band corresponding to the reference ( $\mathrm{C}-\mathrm{H}$ bonds).

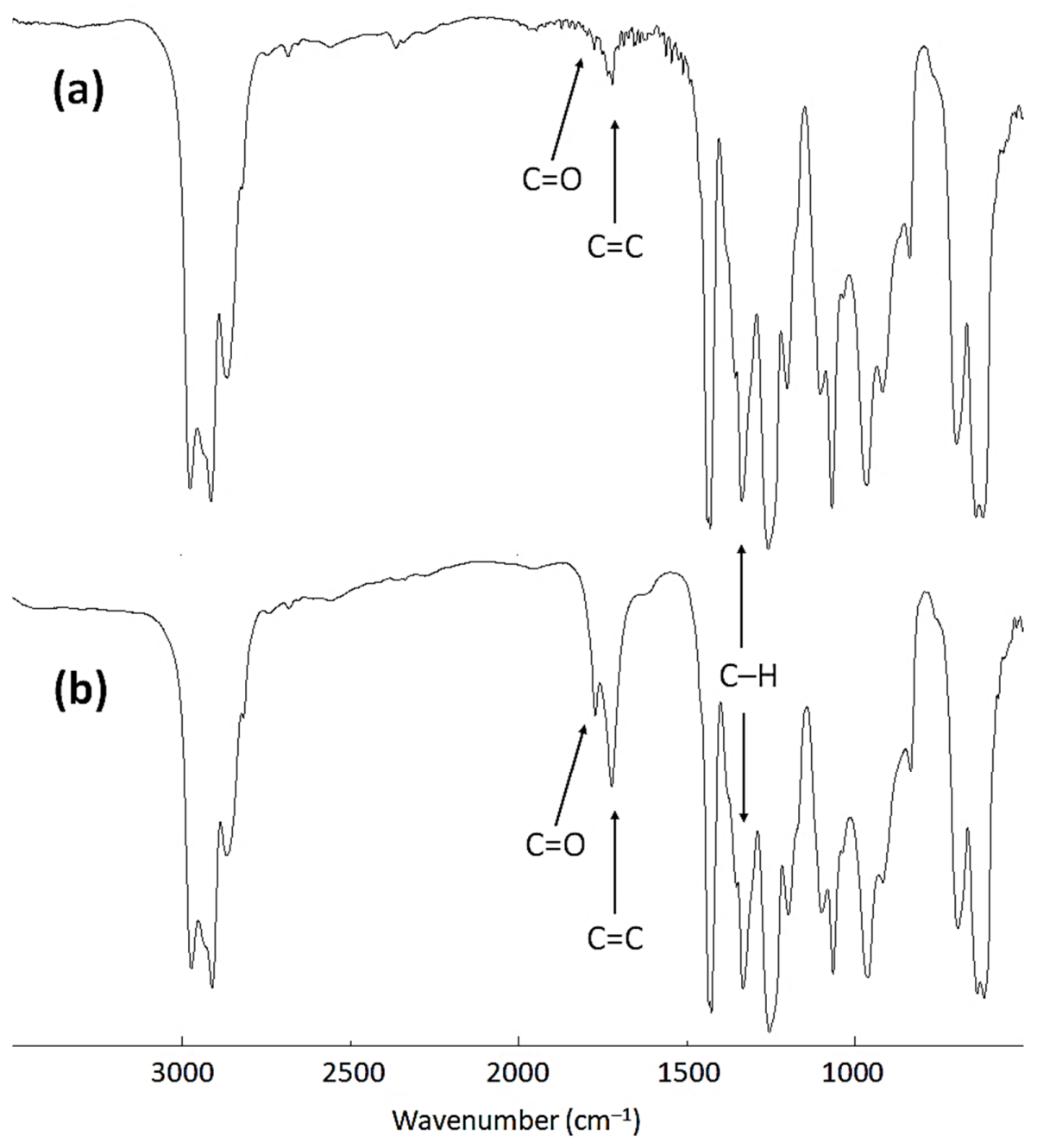

Figure 1. FTIR spectra of the pure PVC film pre- and post-irradiation.

Equation (1) has been used to calculate the indices of both $\mathrm{C}=\mathrm{O}\left(I_{C=O}\right)$ and $\mathrm{C}=\mathrm{C}\left(I_{C=C}\right)$ groups for the pure PVC film and the blends containing 1-3 after every $50 \mathrm{~h}$ of irradiation. The changes in $I_{C=O}$ and $I_{C=C}$ for the PVC during irradiation are shown in Figures 2 and 3, respectively. It was clear that the changes in the $I_{C=O}$ and $I_{C=C}$ were significantly higher and sharper in the case of the pure PVC film. Complexes 1-3 evidently reduced the formation of small fragments containing $\mathrm{C}=\mathrm{O}$ and $\mathrm{C}=\mathrm{C}$ groups and hence acted as $\mathrm{PVC}$ photostabilizers. For the pure PVC film, the $I_{C=C}$ was 0.53 after 50 h, 0.80 after 100 h, 1.01 after $200 \mathrm{~h}$, and 1.51 after $300 \mathrm{~h}$ of irradiation. The PVC film containing 1 showed the lowest $I_{C=O}$ at 0.26 after $50 \mathrm{~h}, 0.40$ after $100 \mathrm{~h}, 0.58$ after $200 \mathrm{~h}$, and 0.71 after $300 \mathrm{~h}$ of irradiation. The superior ability 
of complex $\mathbf{1}$ to act as a UV absorber is ascribed to the three phenyl group substituents. A similar pattern is observed for the changes in $I_{C=C}$.

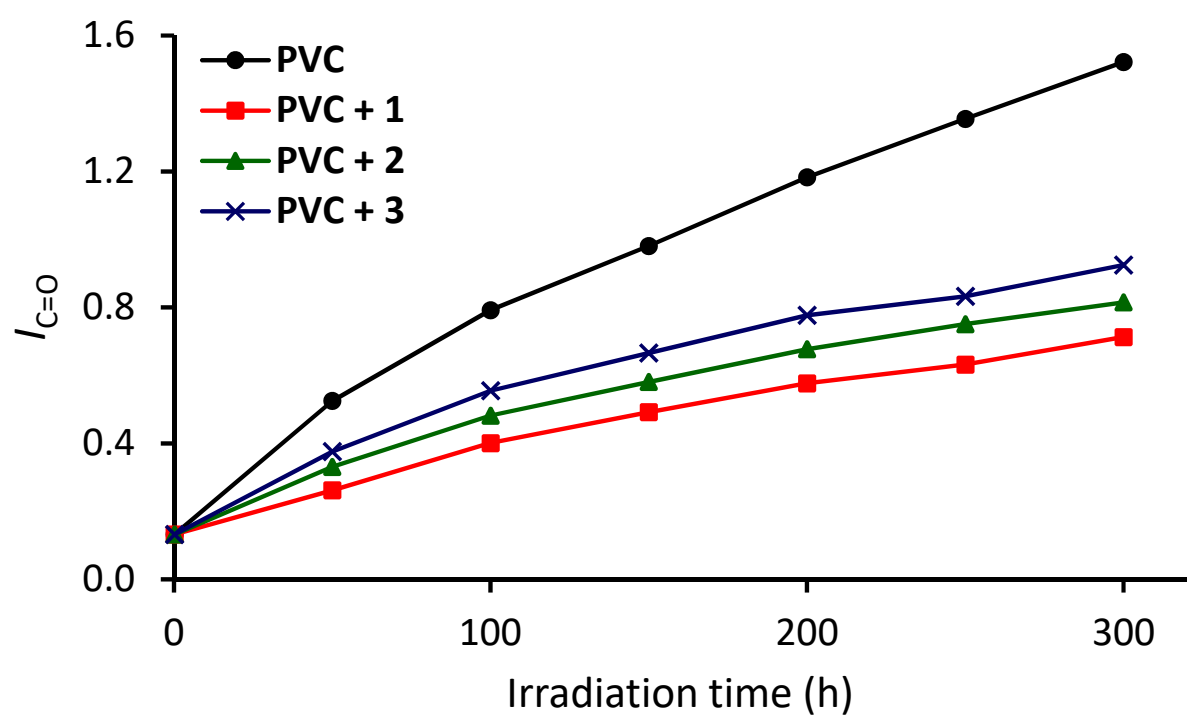

Figure 2. Changes in the $I_{C=O}$ index of PVC films.

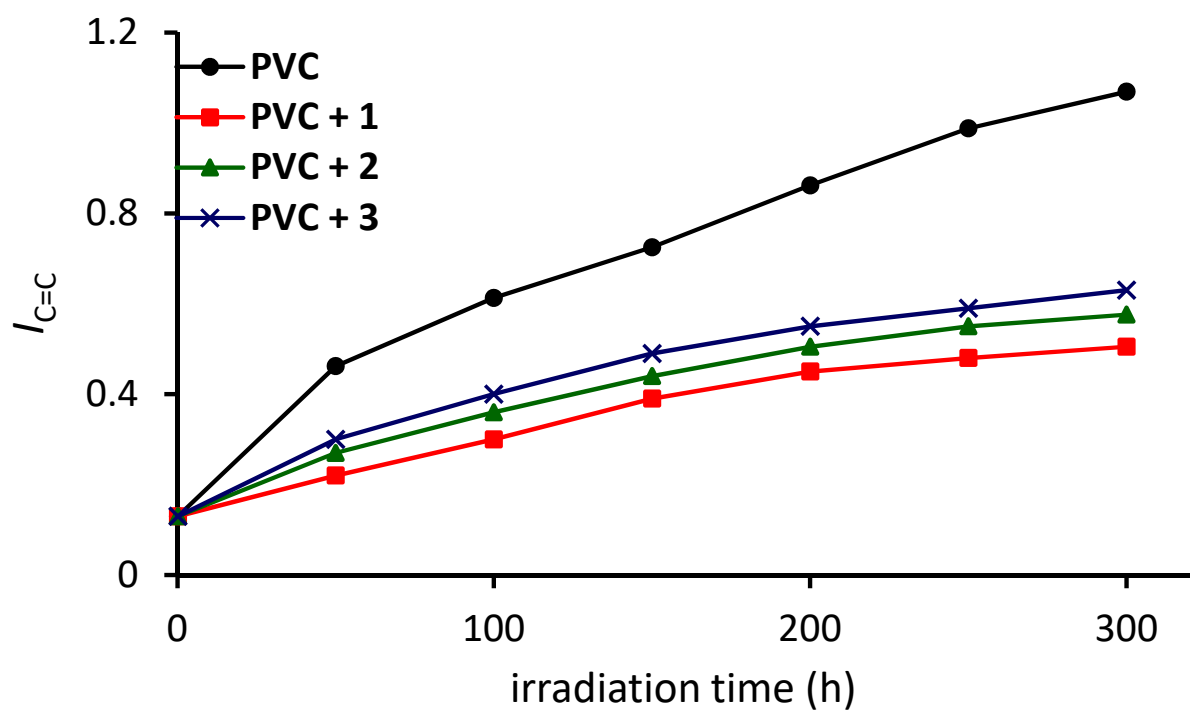

Figure 3. Changes in the $I_{C=C}$ index of PVC films.

\subsection{Investigation of PVC Photodegradation through Weight Loss}

PVC photo-oxidation and photodecomposition lead to cross-linking and bond breaking resulting in the formation of volatiles such as $\mathrm{HCl}$, and the production of small polymeric fragments. The outcome is weight loss by the PVC sample which increases with irradiation time [44]. The damage induced in the PVC chains can be assessed by measuring weight during irradiation and using Equation (2) to calculate the percentage weight loss. The percentage weight losses for the samples as a function of irradiation time $(0-300 \mathrm{~h})$ are shown in Figure 4. Relative to the other samples, a sharp weight loss was observed in the first $50 \mathrm{~h}$ for the pure PVC sample before settling to a rate fairly similar to the other samples. The weight loss (\%) was $0.21 \%$ after $50 \mathrm{~h}$ and $0.70 \%$ after $300 \mathrm{~h}$ of irradiation for the pure PVC. The trimethoprim-tin complexes led to a significant drop in the weight loss of PVC. Complex 1 led to the most significant reduction followed by 2 and then by 3 . The blend containing 1 showed a weight loss (\%) of $0.05 \%$ after $50 \mathrm{~h}$ and $0.32 \%$ at the end of 
irradiation. These results are in agreement with those obtained from FTIR and functional group indices.

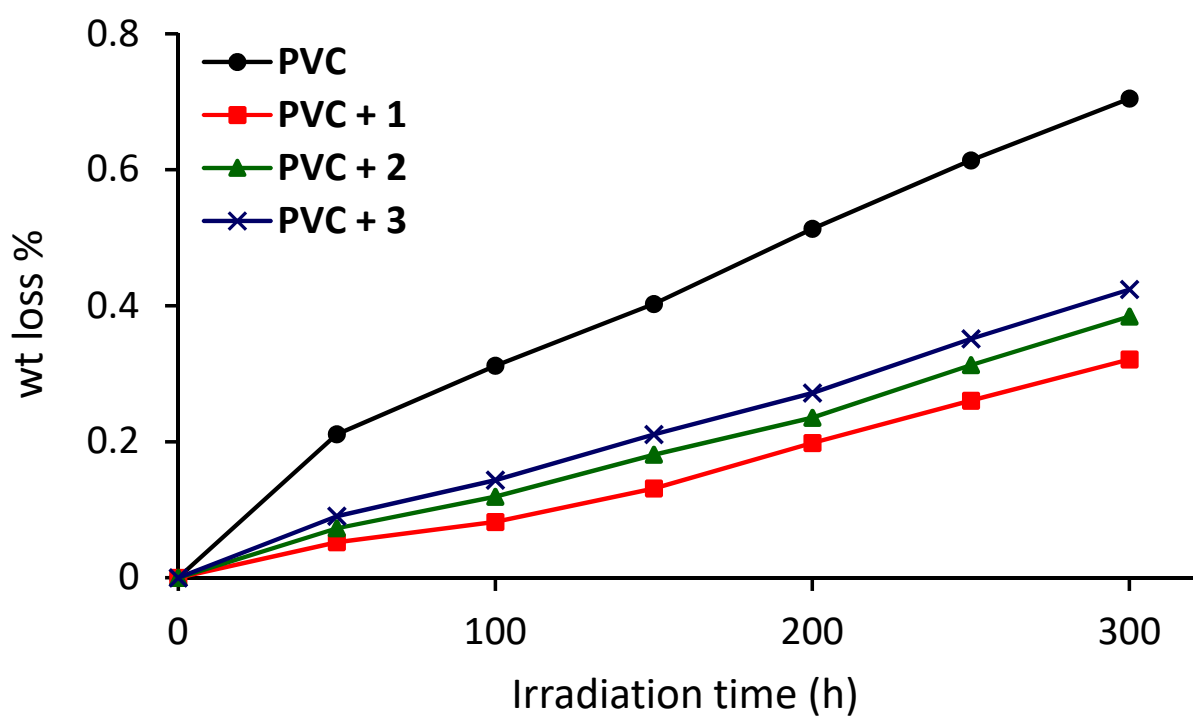

Figure 4. Changes in weight loss (\%) of PVC films.

\subsection{Investigation of PVC Photodegradation through Surface Morphology}

Changes on the surface of the PVC film can give an indication of damage during irradiation. With damage, microscope images of the surface of PVC films recorded postirradiation would show irregularities when compared with pre-irradiation images. The images for the samples are shown in Figure 5.

In general, the number of cracks, dark spots, and grooves is more noticeable postirradiation. The appearance of the dark spots is mainly due to the release of $\mathrm{HCl}$ because of PVC decomposition [45]. The dark spots were most noticeable on the surface of the pure PVC film. The surface of the blend containing 2 was almost smooth with no groves or crakes. The surface of the blend containing 3 showed some dark spots and irregularities. The surface of the blend containing $\mathbf{1}$ showed the presence of dark areas which appeared to be rod-shaped. It is not clear why such rodlike shapes were only seen in the case of $\mathbf{1}$. However, it could have something to do with the rate of the elimination of volatiles during the photodegradation process. In an attempt to understand the changes on the surface of the PVC blend containing $\mathbf{1}$, it was decided to use an additional technique, namely FESEM.

The FESEM images gave clearer less distorted and high-resolution pictures of the PVC surface. The images provided information about the homogeneity of the surface as well as the particles size and shape for the irradiated materials [46]. Figure 6 shows that the surface of irradiated PVC films contains lumps, groves, and noticeable irregularities attributed to bond cleavage during photoirradiation and photodegradation [47]. The size of the particles varies; $42.07-132.9 \mathrm{~nm}$ for $1,69.11-164.8 \mathrm{~nm}$ for 2, and $42.07-152.3 \mathrm{~nm}$ for 3 . Again, the surface of the blend containing 1 shows cracks and rodlike particles, which is consistent with the microscope image (Figure 6). It has been reported that PVC containing nickel chloride and a dithiazole Schiff base or tin-naphthalene sulfonic acid complex led to the formation of honeycomb-like structures $[31,38]$. In addition, PVC blended with a Schiff base containing a melamine unit showed an ice-rock structure [36]. Such observations could be attributed to the slow rate of $\mathrm{HCl}$ elimination from the PVC chains during photoirradiation. Figure 7 shows the FESEM images of the particles within the PVC $+\mathbf{1}$ film post- irradiation at lower magnification. 
Pre-irradiation

(a)

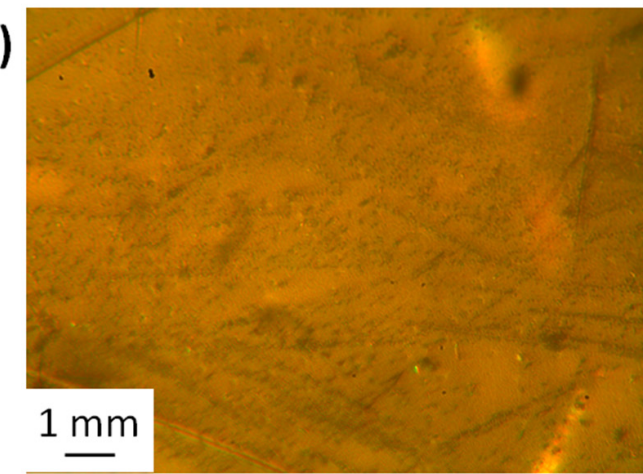

(b)

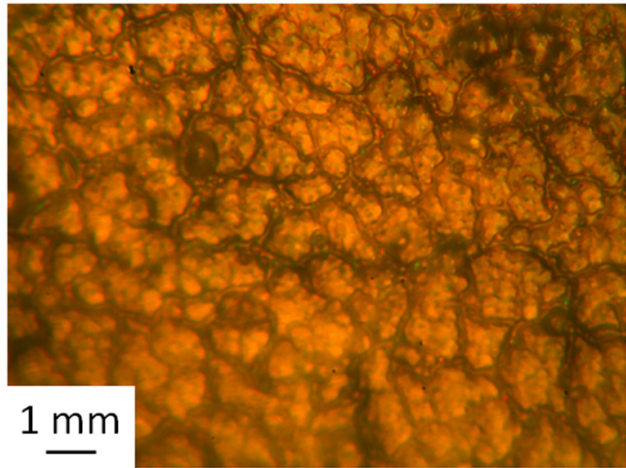

(c)

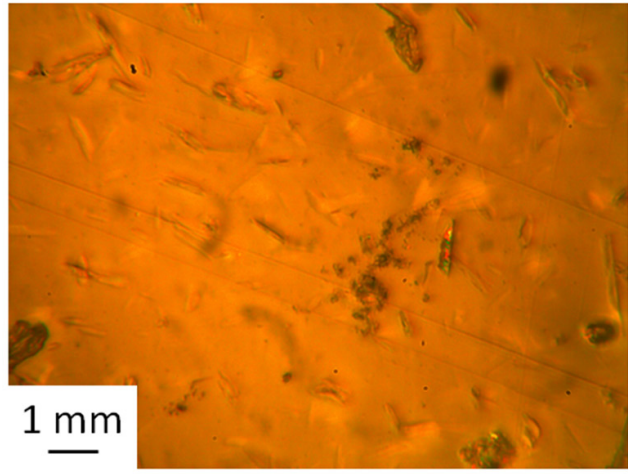

(d)

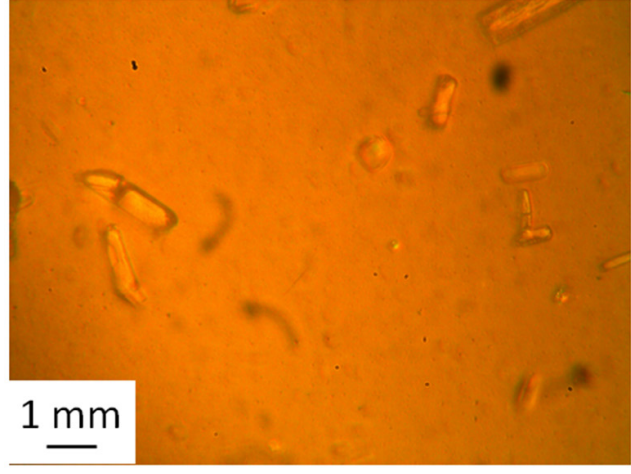

Post-irradiation
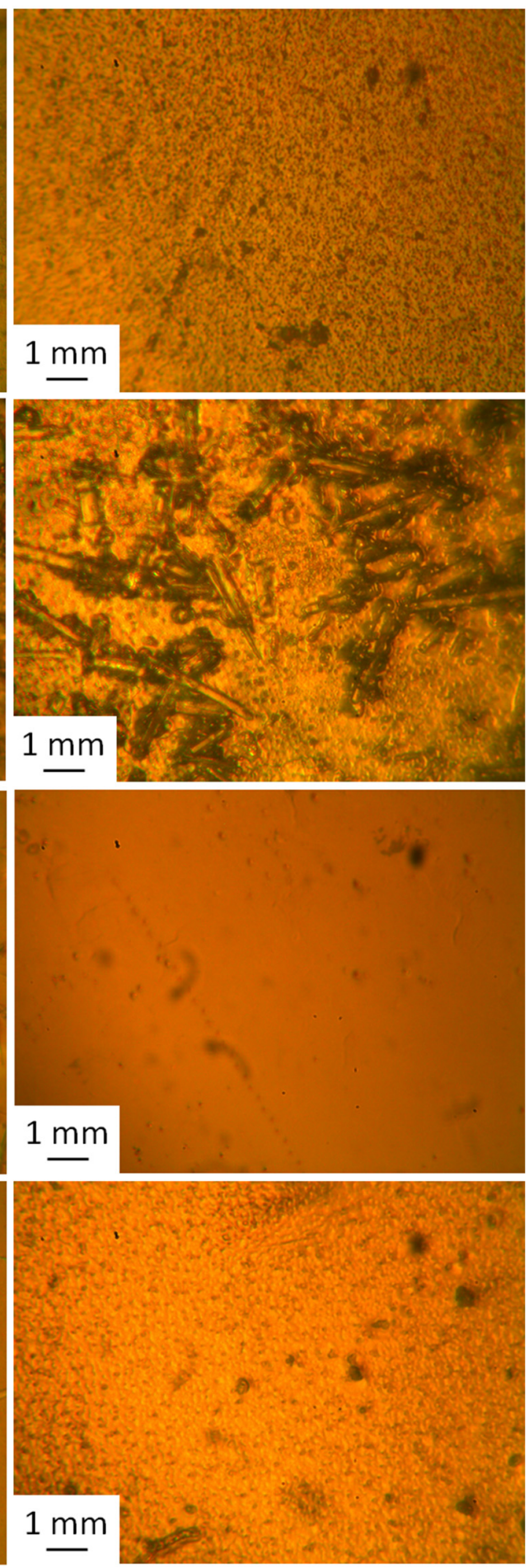

Figure 5. Microscope images of: (a) PVC blank (b) PVC +1 , (c) PVC +2 , and (d) PVC +3 blends both before and after irradiation.

AFM has also been used to analyze the surface of the irradiated PVC films. Previous reports showed that non-irradiated polymeric films have a high level of homogeneity and smoothness $[48,49]$. On the other hand, the AFM images of the irradiated blends showed that the surface was badly damaged due to bond cleavage (Figure 8). The surface of the irradiated blends was rough and contained dark spots, particularly in the case of the pure PVC film. Complexes 1-3 reduced the damage caused by photoirradiation, leading to a 
smoother surface. The roughness factor $(R q)$ for the irradiated pure PVC film was 295.2, which is much higher than for the blends containing the tin complexes. The $R q$ for the PVC blends containing 1, 2, and 3 were 26.1, 38.6, and 51.2, respectively. Clearly, the trimethoprim-tin complexes caused a significant reduction in the $R q$ values. For example, complex 1 led to a reduction in the $R q$ by 11.3-fold, which is higher than that achieved with many other organometallic complexes (Table 4).
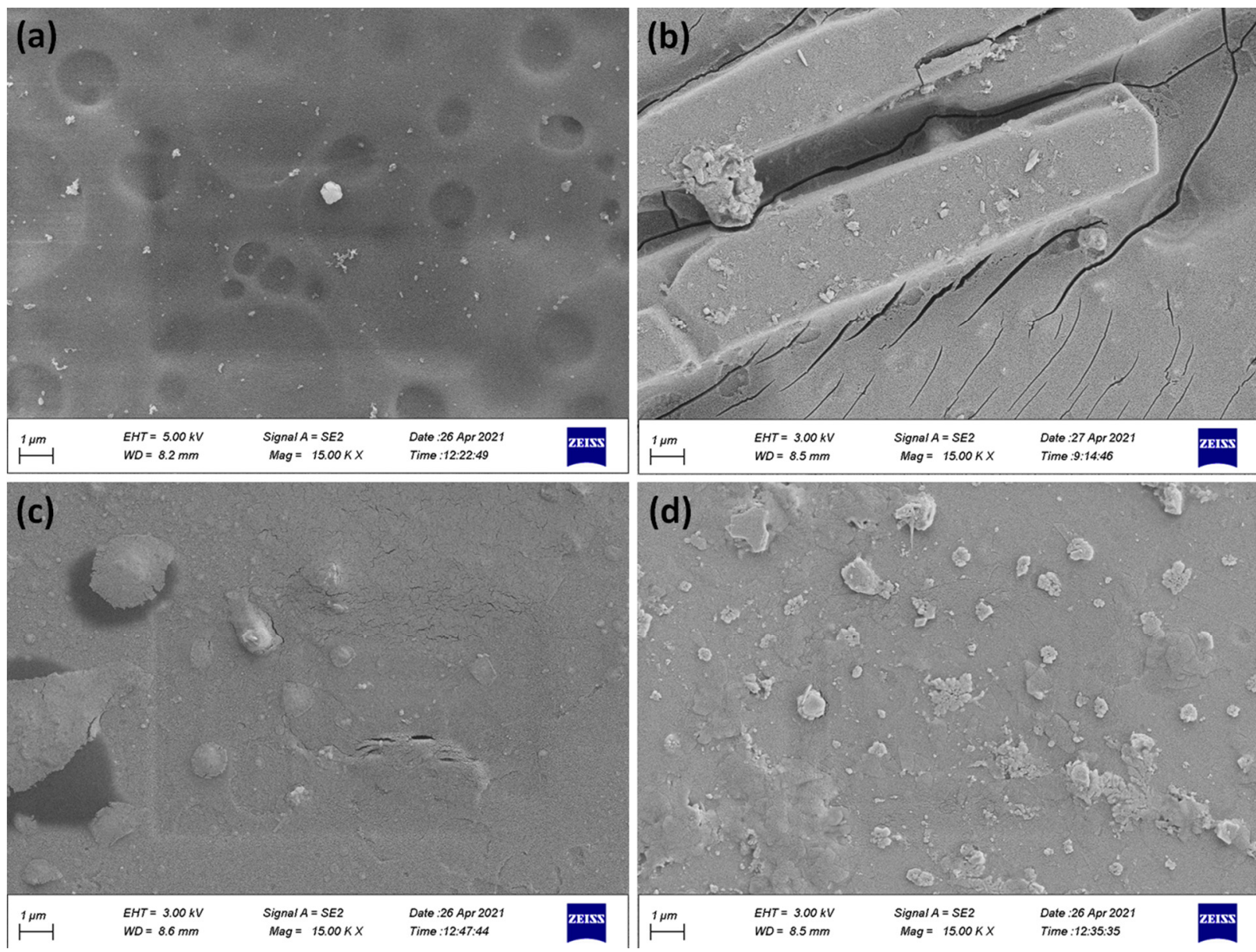

Figure 6. FESEM images of (a) PVC, (b) PVC +1 , (c) PVC +2 and (d) PVC +3 films after irradiation.
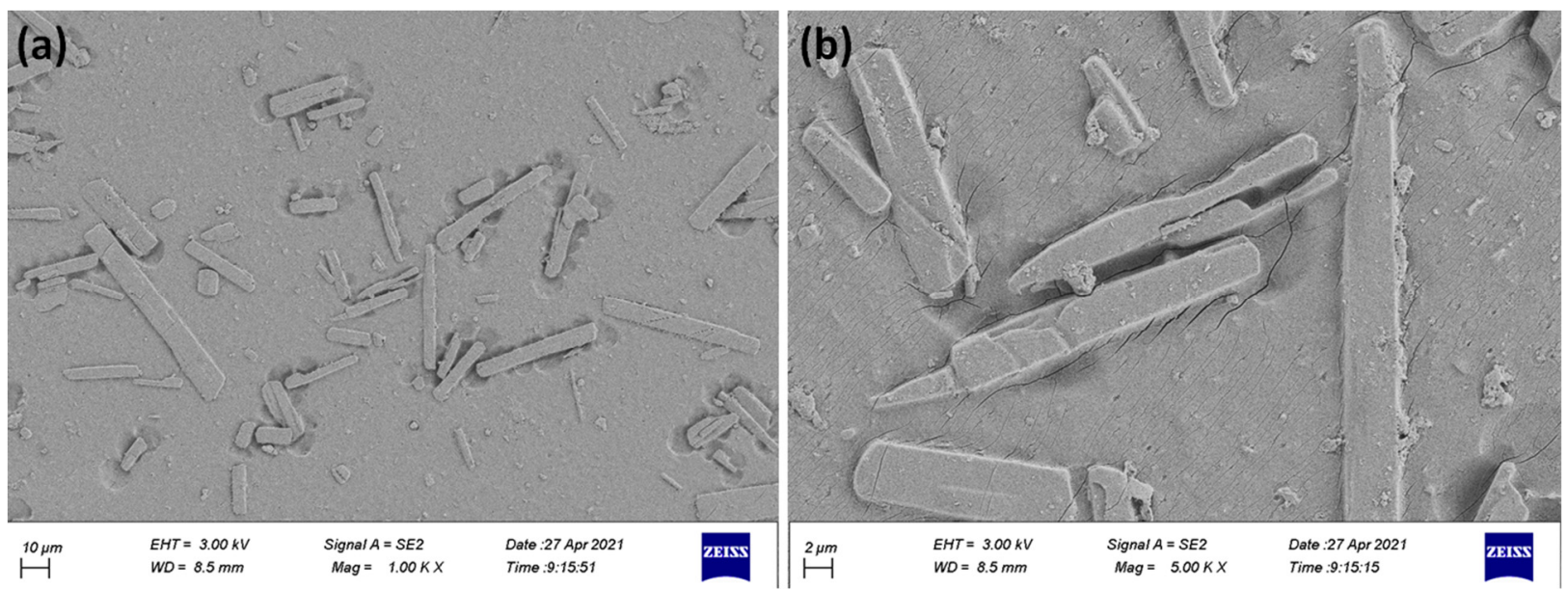

Figure 7. FESEM images of PVC $+\mathbf{1}$ films after irradiation (a) $1 \times$ and (b) $5 \times$ magnification. 
(a)
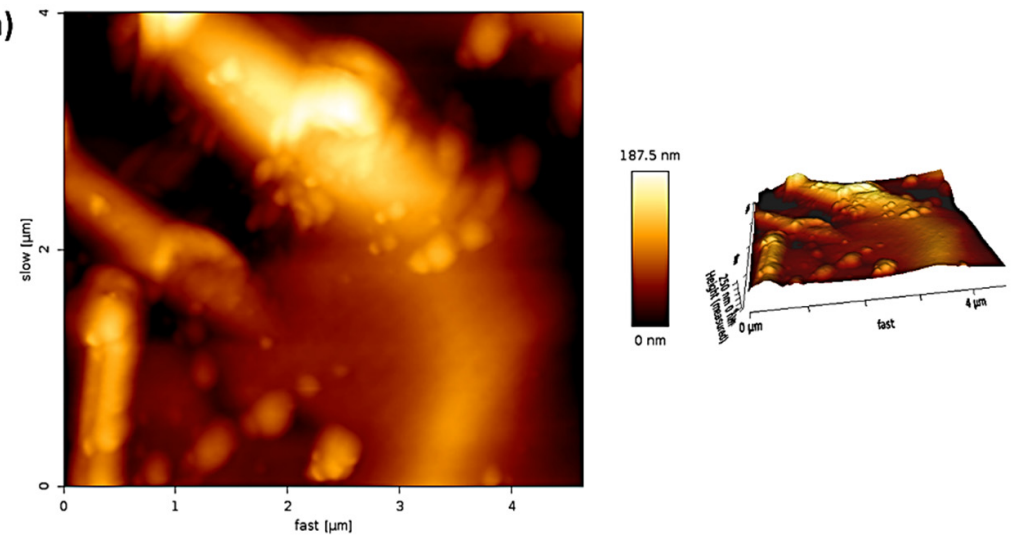

(b)
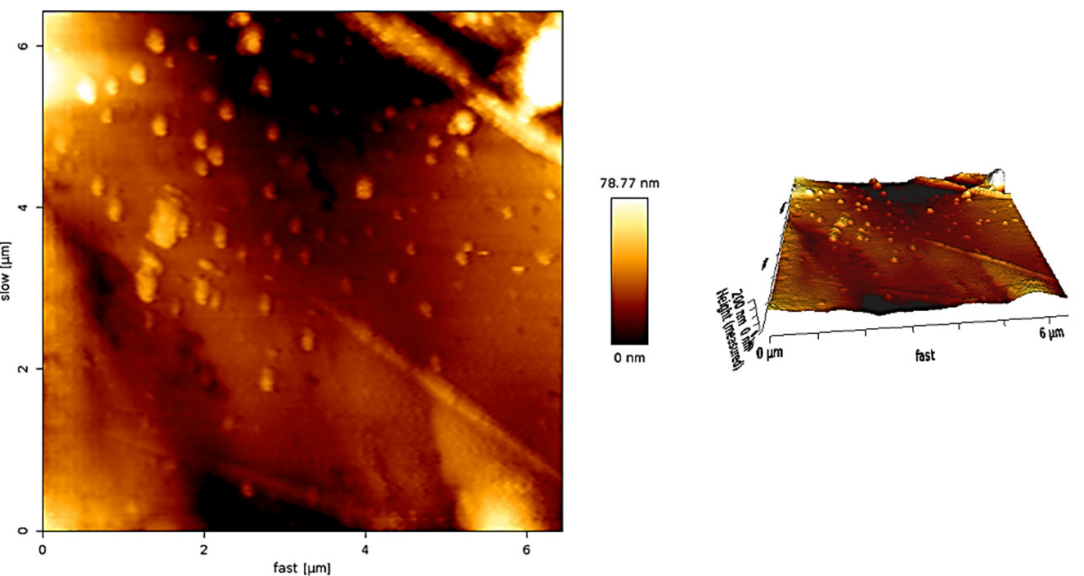

(c)
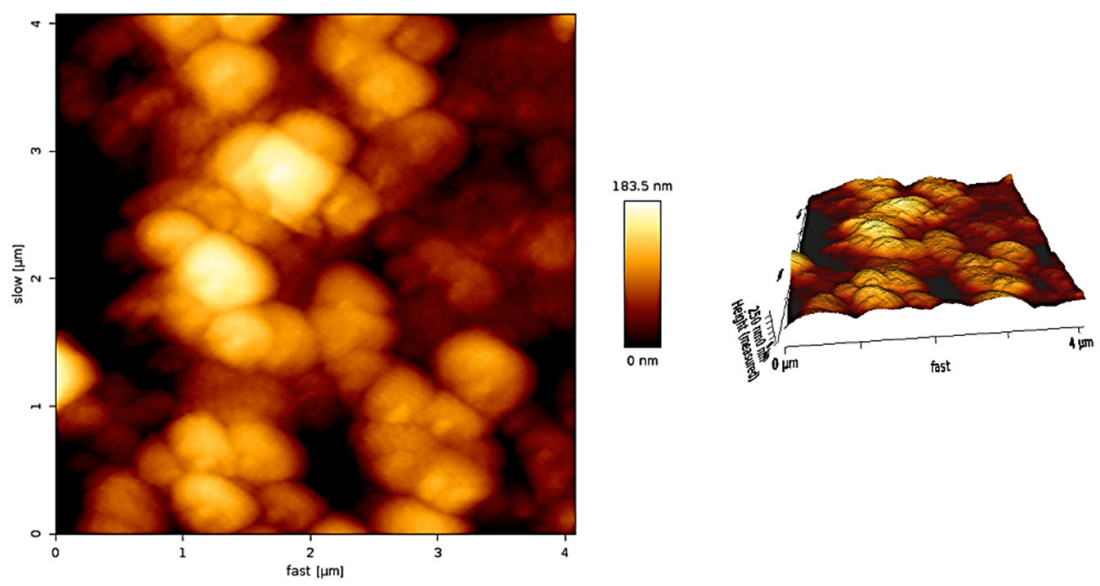

(d)

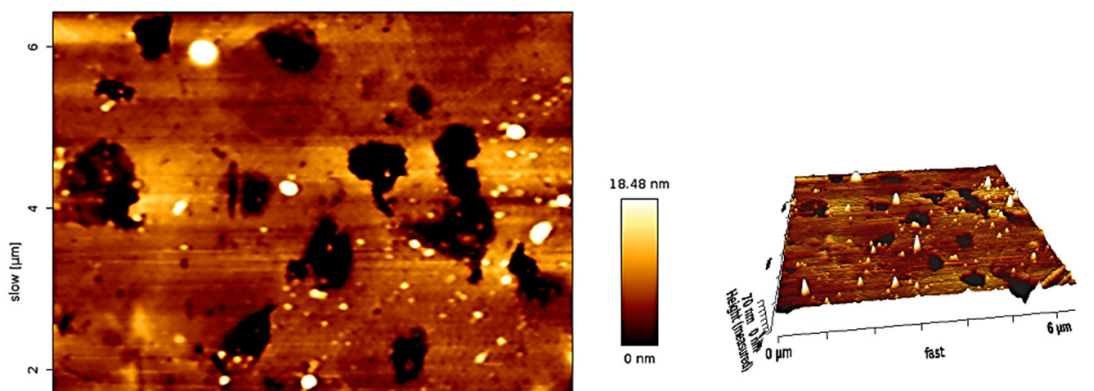

Figure 8. AFM images of (a) PVC, (b) PVC +1 , (c) PVC +2 and (d) PVC +3 films. 
Table 4. Effect of various organotin complexes on the $R q$ for PVC films.

\begin{tabular}{ccc}
\hline PVC Additive & $\boldsymbol{R} \boldsymbol{q}$ Reduction (Fold) & Reference \\
\hline Trimethoprim-tin complexes & 11.3 & [current work] \\
Naproxen-tin complexes & 5.2 & {$[50]$} \\
2-(4-Isobutylphenyl)propanoate-nickel complexes & 6.3 & {$[51]$} \\
Carvedilol-tin complexes & 6.4 & {$[36]$} \\
Furosemide-tin complexes & 6.6 & {$[52]$} \\
Valsartan-tin complexes & 7.4 & {$[53]$} \\
Telmisartan-tin complexes & 9.4 & {$[54]$} \\
Ciprofloxacin-tin complexes & 16.6 & {$[55]$} \\
4-(Benzylideneamino)benzenesulfonamide-tin & 18.4 & {$[56]$} \\
\hline
\end{tabular}

\subsection{PVC Photostabilization Mechanisms}

Trimethoprim-tin complexes 1-3 act as efficient PVC photostabilizers as they are able to absorb UV light. The complexes contain aromatic rings that stabilize the highly energetic intermediates formed on irradiation through resonance [57]. The tin complexes can also decompose hydroperoxide (Figure 9), which is produced during photo-oxidation of PVC [58]. In addition, the tin atom is capable of scavenging the $\mathrm{HCl}$ (Figure 9) produced during the irradiation process [52]. Both PVC and tin complexes contain polar bonds (e.g., $\mathrm{C}-\mathrm{Cl}$ in $\mathrm{PVC}$ and $\mathrm{C}-\mathrm{O}$ and $\mathrm{C}-\mathrm{N}$ in tin complexes) that allow coordination between them, leading to easier energy transfer from the polymeric chains to the additives (Figure 10). However, complications, such as steric hindrance, that may be associated with large molecules would make such a possibility less likely [53].

(a)
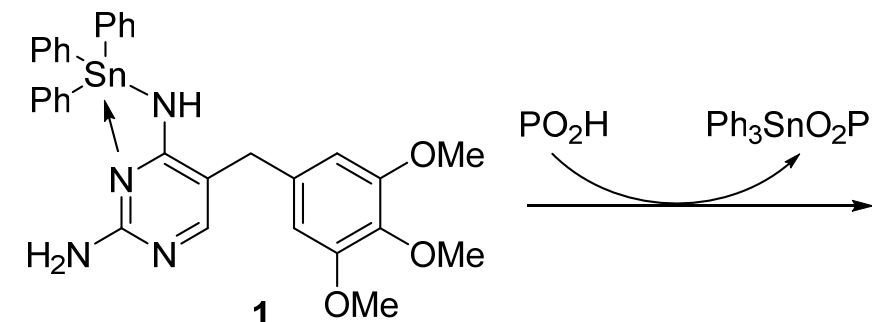<smiles>COc1cc(Cc2cnc(N)nc2N)cc(OC)c1OC</smiles>

(b)<smiles></smiles><smiles></smiles><smiles>COc1cc(Cc2cnc(N)nc2N)cc(OC)c1OC</smiles>

Figure 9. PVC stabilization in the presence of $\mathbf{1}$ by acting as (a) a peroxide decomposer and (b) a $\mathrm{HCl}$ scavenger.

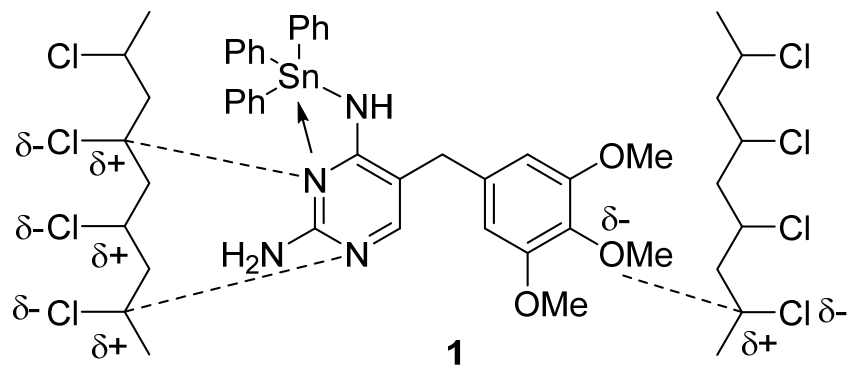

Figure 10. Interaction between complex 1 and PVC. 


\section{Conclusions}

A convenient method for the production of trimethoprim-tin complexes in good yield has been established. The trimethoprim-tin complexes have been shown to act as PVC photostabilizers, leading to a significant reduction in the damage caused by photo-oxidation and photodegradation of the polymeric chains. The additives contain aromatic and heterocyclic moieties that enable them to act as absorbers for ultraviolet light, quenchers for free radicals, and decomposers for hydroperoxides. In addition, the heteroatoms (oxygen and nitrogen) within the trimethoprim-tin complexes facilitate their coordination and interaction with PVC chains. The additives led to a significant decrease in the roughness factor of the PVC surface compared with many other organotin complexes. The additives containing aromatic substituents (phenyl groups) showed better performance as PVC photostabilizers compared with the one containing aliphatic substituents ( $n$-butyl groups).

Supplementary Materials: The following are available online at https:/ / www.mdpi.com/article/10 .3390/polym13193264/s1, Figure S1: FTIR spectrum of 1; Figure S2: FTIR spectrum of 2; Figure S3: FTIR spectrum of 3; Figure S4: ${ }^{1} \mathrm{H}$ NMR spectrum of 3; and Figure S5: ${ }^{13} \mathrm{C}$ NMR spectrum of 3.

Author Contributions: Conceptualization and experimental design: E.Y., E.T.B.A.-T., G.A.E.-H. and D.S.A.; Experimental work and data analysis: A.A.Y.; writing-original draft preparation: E.Y., E.T.B.A.-T., G.A.E.-H., B.M.K., D.S.A. and M.B.; writing—review and editing: E.Y., G.A.E.-H., B.M.K. and D.S.A. All authors have read and agreed to the published version of the manuscript.

Funding: The authors thank the Researchers Supporting Project number (RSP-2021/404), King Saud University, Riyadh, Saudi Arabia.

Institutional Review Board Statement: Not applicable.

Informed Consent Statement: Not applicable.

Data Availability Statement: Data are contained within the article.

Acknowledgments: We thank Tikrit and Al-Nahrain Universities for technical support. The authors thank the Researchers Supporting Project number (RSP-2021/404), King Saud University, Riyadh, Saudi Arabia.

Conflicts of Interest: The authors declare no conflict of interest. The funders had no role in the design of the study; in the collection, analyses, or interpretation of data; in the writing of the manuscript, or in the decision to publish the results.

\section{References}

1. Millet, H.; Vangheluwe, P.; Block, C.; Sevenster, A.; Garcia, L.; Antonopoulos, R. The Nature of Plastics and Their Societal Usage. In Plastics and the Environment; Royal Society of Chemistry: Cambridge, UK, 2018; pp. 1-20. [CrossRef]

2. Andrady, A.L.; Neal, M.A. Applications and societal benefits of plastics. Philos. Trans. R. Soc. Lond. B Biol. Sci. 2009, 364, 1977-1984. [CrossRef]

3. Geyer, R.; Jambeck, J.R.; Law, K.L. Production, use, and fate of all plastics ever made. Sci. Adv. 2017, 3, e1700782. [CrossRef]

4. Plastics-The Facts 2019. An Analysis of European Plastics Production, Demand and Waste Data. Available online: https://www. plasticseurope.org/application/files/9715/7129/9584/FINAL_web_version_Plastics_the_facts2019_14102019.pdf (accessed on 24 August 2021).

5. Ma, Y.-F.; Liao, S.-L.; Li, Q.-G.; Guan, Q.; Jia, P.-Y.; Zhou, Y.-H. Physical and chemical modifications of poly(vinyl chloride) materials to prevent plasticizer migration-Still on the run. React. Funct. Polym. 2019, 147, 104458. [CrossRef]

6. Patrick, S.G. Practical Guide to Polyvinyl Chloride; Rapra Technology Limited: Shrewsbury, UK, 2005.

7. Guo, Y.; Leroux, F.; Tian, W.; Li, D.; Tang, P.; Feng, Y. Layered double hydroxides as thermal stabilizers for poly(vinyl chloride): A review. Appl. Clay Sci. 2021, 211, 106198. [CrossRef]

8. Walters, P.; Cadogan, D.F.; Howick, C.J. Plasticizers. In Ullmann's Encyclopedia of Industrial Chemistry; Wiley-VCH: Weinheim, Germany, 2020. [CrossRef]

9. Maeda, Y.; Paul, D.R. Effect of antiplasticization on gas sorption and transport. I. Polysulfone. J. Polym. Sci. Part B Polym. Phys. 1987, 25, 957-980. [CrossRef]

10. Maeda, Y.; Paul, D.R. Effect of antiplasticization on gas sorption and transport. III. Free volume interpretation. J. Polym. Sci. Part B Polym. Phys. 1987, 25, 1005-1016. [CrossRef]

11. Wypych, G. PVC Degradation and Stabilization, 3rd ed.; ChemTec Publishing: Scarborough, ON, Canada, 2015. [CrossRef] 
12. Huang, Z.; Ding, A.; Guo, H.; Lu, G.; Huang, X. Construction of nontoxic polymeric UV-absorber with great resistance to UV-photoaging. Sci. Rep. 2016, 6, 25508. [CrossRef] [PubMed]

13. Rabek, J.F. Polymer Photodegradation-Mechanisms and Experimental Methods; Chapman \& Hall: London, UK, 1995.

14. Veronelli, M.; Mauro, M.; Bresadpla, S. Influence of thermal dehydrochlorination on the photooxidation kinetics of PVC samples. Polym. Degrad. Stab. 1999, 66, 349-357. [CrossRef]

15. Yu, J.; Sun, L.; Ma, C.; Qiao, Y.; Yao, H. Thermal degradation of PVC: A review. Waste Manag. 2016, 48, 300-314. [CrossRef]

16. Lucarini, M.; Pedulli, G.F. Free radical intermediates in the inhibition of the autoxidation reaction. Chem. Soc. Rev. 2010, 39, 2106-2119. [CrossRef]

17. Gryn'ova, G.; Hodgson, J.L.; Coote, M.L. Revising the mechanism of polymer autooxidation. Org. Biomol. Chem. 2011, 9, 480-490. [CrossRef]

18. Karayıldırım, T.; Yanık, J.; Yüksel, M.; Saglam, M.; Haussmann, M. Degradation of PVC containing mixtures in the presence of $\mathrm{HCl}$ fixators. J. Polym. Environ. 2005, 13, 365-379. [CrossRef]

19. Mohamed, N.A.; Yassin, A.A.; Khalil, K.D.; Sabaa, M.W. Organic thermal stabilizers for rigid poly(vinyl chloride) I. Barbituric and thiobarbituric acids. Polym. Degrad. Stab. 2000, 70, 5-10. [CrossRef]

20. Grossman, R.F. Mixed metal vinyl stabilizer synergism. II: Reactions with zinc replacing cadmium. J. Vinyl Addit. Technol. 1990, 12, 142-145. [CrossRef]

21. Porta, M.; Zumeta, E. Implementing the Stockholm treaty on persistent organic pollutants. Occup. Environ. Med. 2002, 59, 651-652. [CrossRef]

22. Li, D.; Xie, L.; Fu, M.; Zhang, J.; Indrawirawan, S.; Zhang, Y.; Tang, S. Synergistic effects of lanthanum-pentaerythritol alkoxide with zinc stearates and with beta-diketone on the thermal stability of poly(vinyl chloride). Polym. Degd. Stab. 2015, 114, 52-59. [CrossRef]

23. Fu, M.; Li, D.; Liu, H.; Ai, H.; Zhang, Y.; Zhang, L. Synergistic effects of zinc-mannitol alkoxide with calcium/zinc stearates and with $\beta$-diketone on thermal stability of rigid poly(vinyl chloride). J. Polym. Res. 2016, 23, 13. [CrossRef]

24. El-Hiti, G.A.; Ahmed, D.S.; Yousif, E.; Alotaibi, M.H.; Star, H.A.; Ahmed, A.A. Influence of polyphosphates on the physicochemical properties of poly(vinyl chloride) after irradiation with ultraviolet light. Polymers 2020, 12, 193. [CrossRef] [PubMed]

25. Jin, D.; Khanal, S.; Zhang, C.; Xu, S. Photodegradation of polybenzimidazole/polyvinyl chloride composites and polybenzimidazole: Density functional theory and experimental study. J. Appl. Polym. Sci. 2021, 138, 49693. [CrossRef]

26. Chakrabarti, S.; Chaudhuri, B.; Bhattacharjee, S.; Das, P.; Dutta, B.K. Degradation mechanism and kinetic model for photocatalytic oxidation of PVC-ZnO composite film in presence of a sensitizing dye and UV radiation. J. Hazard. Mater. 2008, 154, 230-236. [CrossRef]

27. Yang, T.C.; Noguchi, T.; Isshiki, M.; Wu, J.H. Effect of titanium dioxide particles on the surface morphology and the mechanical properties of PVC composites during QUV accelerated weathering. Polym. Compos. 2016, 37, 3391-3397. [CrossRef]

28. Yang, T.C.; Noguchi, T.; Isshiki, M.; Wu, J.H. Effect of titanium dioxide on chemical and molecular changes in PVC sidings during QUV accelerated weathering. Polym. Degrad. Stab. 2014, 104, 33-39. [CrossRef]

29. Schiller, M. PVC Additives: Performance, Chemistry, Developments, and Sustainability; Carl Hanser Verlag: Munich, Germany, 2015.

30. Ahmed, A.A.; Ahmed, D.S.; El-Hiti, G.A.; Alotaibi, M.H.; Hashim, H.; Yousif, E. SEM morphological analysis of irradiated polystyrene film doped by a Schiff base containing a 1,2,4-triazole ring system. Appl. Petrochem. Res. 2019, 9, 169-177. [CrossRef]

31. Hashim, H.; El-Hiti, G.A.; Alotaibi, M.H.; Ahmed, D.S.; Yousif, E. Fabrication of ordered honeycomb porous poly(vinyl chloride) thin film doped with a Schiff base and nickel(II) chloride. Heliyon 2018, 4, e00743. [CrossRef]

32. Shaalan, N.; Laftah, N.; El-Hiti, G.A.; Alotaibi, M.H.; Muslih, R.; Ahmed, D.S.; Yousif, E. Poly(vinyl chloride) photostabilization in the presence of Schiff bases containing a thiadiazole moiety. Molecules 2018, 23, 913. [CrossRef]

33. Ali, G.Q.; El-Hiti, G.A.; Tomi, I.H.R.; Haddad, R.; Al-Qaisi, A.J.; Yousif, E. Photostability and performance of polystyrene films containing 1,2,4-triazole-3-thiol ring system Schiff bases. Molecules 2016, 21, 1699. [CrossRef]

34. Balakit, A.A.; Ahmed, A.; El-Hiti, G.A.; Smith, K.; Yousif, E. Synthesis of new thiophene derivatives and their use as photostabilizers for rigid poly(vinyl chloride). Int. J. Polym. Sci. 2015, 2015, 510390. [CrossRef]

35. Ahmed, A.; El-Hiti, G.A.; Hadi, A.G.; Ahmed, D.S.; Baashen, M.A.; Hashim, H.; Yousif, E. Photostabilization of poly(vinyl chloride) films blended with organotin complexes of mefenamic acid for outdoor applications. Appl. Sci. 2021, 11, 2853. [CrossRef]

36. Mousa, O.G.; El-Hiti, G.A.; Baashen, M.A.; Bufaroosha, M.; Ahmed, A.; Ahmed, A.A.; Ahmed, D.S.; Yousif, E. Synthesis of carvedilol-organotin complexes and their effects on reducing photodegradation of poly(vinyl chloride). Polymers 2021, 13, 500. [CrossRef] [PubMed]

37. Mahmood, Z.N.; Yousif, E.; Alias, M.; El-Hiti, G.A.; Ahmed, D.S. Synthesis, characterization, properties, and use of new fusidate organotin complexes as additives to inhibit poly(vinyl chloride) photodegradation. J. Polym. Res. 2020, 27, 267. [CrossRef]

38. Jasem, H.; Hadi, A.G.; El-Hiti, G.A.; Baashen, M.A.; Hashim, H.; Ahmed, A.A.; Ahmed, D.S.; Yousif, E. Tin-naphthalene sulfonic acid complexes as photostabilizers for poly(vinyl chloride). Molecules 2021, 26, 3629. [CrossRef]

39. Crellin, E.; Mansfield, K.E.; Leyrat, C.; Nitsch, D.; Douglas, I.J.; Root, A.; Williamson, E.; Smeeth, L.; Tomlinson, L.A. Trimethoprim use for urinary tract infection and risk of adverse outcomes in older patients: Cohort study. BMJ 2018, 360, k341. [CrossRef]

40. Gaumet, S.; Gardette, J.-L. Photo-oxidation of poly(vinyl chloride): Part 2-A comparative study of the carbonylated products in photo-chemical and thermal oxidations. Polym. Degrad. Stab. 1991, 33, 17-34. [CrossRef] 
41. Pospíšil, J.; Nešpurek, S. Photostabilization of coatings. Mechanisms and performance. Prog. Polym. Sci. 2000, 25, $1261-1335$. [CrossRef]

42. Chaochanchaikul, K.; Rosarpitak, V.; Sombatsompop, N. Photodegradation profiles of PVC compound and wood/PVC composites under UV weathering. Express Polym. Lett. 2013, 7, 146-160. [CrossRef]

43. Nief, O.A. Photostabilization of polyvinyl chloride by some new thiadiazole derivatives. Eur. J. Chem. 2015, 6, 242-247. [CrossRef]

44. Jafari, A.J.; Donaldson, J.D. Determination of $\mathrm{HCl}$ and VOC emission from thermal degradation of PVC in the absence and presence of copper, copper(II) oxide and copper(II) chloride. J. Chem. 2009, 6, 685-692. [CrossRef]

45. Valko, L.; Klein, E.; Kovařík, P.; Bleha, T.; Šimon, P. Kinetic study of thermal dehydrochlorination of poly(vinyl chloride) in the presence of oxygen: III. Statistical thermodynamic interpretation of the oxygen catalytic activity. Eur. Polym. J. 2001, 37, 1123-1132 [CrossRef]

46. Nikafshar, S.; Zabihi, O.; Ahmadi, M.; Mirmohseni, A.; Taseidifar, M.; Naebe, M. The effects of UV light on the chemical and mechanical properties of a transparent epoxy-diamine system in the presence of an organic UV absorber. Materials 2017, 10, 180. [CrossRef] [PubMed]

47. Shi, W.; Zhang, J.; Shi, X.-M.; Jiang, G.-D. Different photo-degradation processes of PVC with different average degrees of polymerization. J. Appl. Polym. Sci. 2008, 107, 528-540. [CrossRef]

48. Yousif, E.; Ahmed, D.S.; El-Hiti, G.A.; Alotaibi, M.H.; Hashim, H.; Hameed, A.S.; Ahmed, A. Fabrication of novel ball-like polystyrene films containing Schiff base microspheres as photostabilizers. Polymers 2018, 10, 1185. [CrossRef] [PubMed]

49. Alotaibi, M.H.; El-Hiti, G.A.; Yousif, E.; Ahmed, D.S.; Hashim, H.; Hameed, A.S.; Ahmed, A. Evaluation of the use of polyphosphates as photostabilizers and in the formation of ball-like polystyrene materials. J. Polym. Res. 2019, 26, 161. [CrossRef]

50. Hadi, A.G.; Yousif, E.; El-Hiti, G.A.; Ahmed, D.S.; Jawad, K.; Alotaibi, M.H.; Hashim, H. Long-term effect of ultraviolet irradiation on poly(vinyl chloride) films containing naproxen diorganotin(IV) complexes. Molecules 2019, 24, 2396. [CrossRef]

51. Mohammed, R.; El-Hiti, G.A.; Ahmed, A.; Yousif, E. Poly(vinyl chloride) doped by 2-(4-isobutylphenyl)propanoate metal complexes: Enhanced resistance to UV irradiation. Arab. J. Sci. Eng. 2017, 42, 4307-4315. [CrossRef]

52. Ali, M.M.; El-Hiti, G.A.; Yousif, E. Photostabilizing efficiency of poly(vinyl chloride) in the presence of organotin(IV) complexes as photostabilizers. Molecules 2016, 21, 1151. [CrossRef] [PubMed]

53. Mohammed, A.; El-Hiti, G.A.; Yousif, E.; Ahmed, A.A.; Ahmed, D.S.; Alotaibi, M.H. Protection of poly(vinyl vhloride) films against photodegradation using various valsartan tin complexes. Polymers 2020, 12, 969. [CrossRef]

54. Hadi, A.G.; Jawad, K.; El-Hiti, G.A.; Alotaibi, M.H.; Ahmed, A.A.; Ahmed, D.S.; Yousif, E. Photostabilization of poly(vinyl chloride) by organotin(IV) compounds against photodegradation. Molecules 2019, 24, 3557. [CrossRef]

55. Ghazi, D.; El-Hiti, G.A.; Yousif, E.; Ahmed, D.S.; Alotaibi, M.H. The effect of ultraviolet irradiation on the physicochemical properties of poly(vinyl chloride) films containing organotin(IV) complexes as photostabilizers. Molecules 2018, 23, 254. [CrossRef]

56. Ghani, H.; Yousif, E.; Ahmed, D.S.; Kariuki, B.M.; El-Hiti, G.A. Tin complexes of 4-(benzylideneamino)benzenesulfonamide: Synthesis, structure elucidation and their efficiency as PVC photostabilizers. Polymers 2021, 13, 2434. [CrossRef]

57. Sabaa, M.W.; Oraby, E.H.; Abdel Naby, A.S.; Mohamed, R.R. Anthraquinone derivatives as organic stabilizers for rigid poly(vinyl chloride) against photo-degradation. Eur. Polym. J. 2005, 41, 2530-2543. [CrossRef]

58. Zheng, X.-G.; Tang, L.-H.; Zhang, N.; Gao, Q.-H.; Zhang, C.-F.; Zhu, Z.-B. Dehydrochlorination of PVC materials at high temperature. Energy Fuels 2003, 17, 896-900. [CrossRef] 